\title{
Racism in English Language Teaching? Autobiographical Narratives of Black English Language Teachers in Brazil ${ }^{1}$
}

\section{Racismo no ensino de língua inglesa? Narrativas autobiográficas de professores negros de língua inglesa no Brasil}

Gabriel Nascimento*2

*Universidade Federal do Sul da Bahia (UFSB), Porto Seguro, Bahia /Brazil gabriel.santos@csc.ufsb.edu.br

https://orcid.org/0000-0002-7695-9264

\begin{abstract}
A hundred thirty years after the abolition of slavery and postslave trade in Brazil, Black people remain the minority amongst teachers in English courses of private and public schools. This situation is tagged in their professional situation insofar as an aftermath of racism and coloniality are concerned, as I shall argue here. In this study, I seek to examine the ways race can be negatively or positively expanded in the performance of the identities of Black English language teachers, framing themselves as either resistant identities in/through language (using the language as a strategy to resist) or resistant identities to language (negating themselves as capable speakers or teachers).
\end{abstract}

KEYWORDS: slavery; black people; black English teachers.

RESUMO: Centro e trinta anos depois da abolição da escravatura as pessoas negras continuam a minoria entre profissionais, educadores e estudiosos em educação em cursos de inglês de escolas públicas e privadas. Essa situação é

\footnotetext{
${ }^{1}$ Many thanks to the professor Lynn Mário Trindade de Meneses e Souza for his careful reading and feedback to several drafts of this article. I also thank the Coordination for Higher Education Staff Development (Capes) for providing a post-graduate grant, which consisted as support to this work (n.000).

${ }^{2}$ Assistant professor at the Institute of Humanities, Arts and Science of the Universidade Federal do Sul da Bahia (Federal University of South Bahia), and prior Visiting Scholar at the Graduate School of Education of the University of Pennsylvania. He holds an M.D. in Applied Linguistics and is currently a Ph.D. candidate in the Linguistic Studies in the English program at the University of São Paulo.
} 
marcada na situação diária de profissionais negros no Brasil até então como uma consequência do racismo e da colonialidade que devo discutir aqui. Neste estudo, eu procuro examinar as formas que a categoria raça pode ganhar negativa ou positivamente na atuação das identidades de professores negros de língua inglesa, que modelam eles mesmos como identidades resistentes na/através da língua (usando a língua/linguagem para resistir) ou identidades resistentes à língua (negando eles próprios como falantes ou professores capazes).

PALAVAS-CHAVE: escravidão; pessoas negras; professores negros de inglês.

\section{Introduction}

"When I say that the expression 'Negro people' is an entity, I thereby indicate that, except for cultural influences, nothing is left. There is as great a difference between a West Indian and a Darkarian as between a Brazilian and a Spaniard. The object of lumping all Negroes together under the designation of 'Negro people' is to deprive them of any possibility of individual expression. What is thus attempted is to put them under the obligation of matching the idea has of them".

(FANON, 1964, p. 17).

Most Brazilian inequalities are an aftermath of the rising racial inequalities throughout centuries of enslavement and decimation of Indigenous and Black ${ }^{3}$ populations in Brazil (MOURA, 2014). However, this is still an issue neglected by acknowledged studies regarding national history and social inequalities in Brazil so far.

According to the last census, Black population in Brazil consists of not only more than 104 million people (54\% of the total population), ${ }^{4}$ but also the major population in jails (more than $60 \%$ of people in jails are Black $)^{5}$ or the majority of victims of violent murders caused by police squads or drug-dealing gangs (every year dozens of thousands of young Black men

\footnotetext{
${ }^{3}$ I have been using "Black" with capital letter in my writings grounded on the arguments of Lori L. Tharps, available at: https:/ /www.nytimes.com/2014/11/19/opinion/the-casefor-black-with-a-capital-b.html.

${ }^{4}$ See also https://agenciadenoticias.ibge.gov.br/agencia-noticias/2012-agencia-denoticias/noticias/18282-pnad-c-moradores.

${ }^{5}$ See also https://www.cartacapital.com.br/sociedade/mais-de-60-dos-presos-no-brasilsao-negros/.
} 
are the victim of violent murders in the country, making up a total number of $77 \%$ of the total young people murdered in 2013 and $71 \%$ of both youth and adults murdered at gunpoint in the same period). ${ }^{6}$ In comparison with White people, Blacks are represented in low proportions in politics, universities, and the most elitist economic spaces (e.g. civil servants of top government positions, university professors, CEOs, etc.).

With this study I argue that my core concerns are with the misrepresentation of Black English language teachers, who are the minority in the programs, colleges, universities and schools. Although teacher development programs occupy a rising discredit over the years (NÓVOA, 2002), there has been a massive inclusion of new Black students in teacher development programs thanks to affirmative actions during Lula's government, taking into account the growing presence of Black students ${ }^{7}$ in universities over the last decade. Despite a rising discredit and a rising presence of Black students in such programs, Black English professors and teachers are still in a low proportion. My experience as a Black and a young English professor and former English teacher at a high school allows me to claim that pre-service and in-service English teachers are White, from middle classes, and thus lack real correspondence with the major racial profile among Brazilian inhabitants: the Black population. In my preliminary concerns in this article, I argue that racism does exist in language education and in teacher's development programs. Moreover, I primarily assume that racism is a constituent in the professional careers pursued by English teachers in Brazil because of both the low proportion of Black English language teachers in Brazil and an elitist-based curriculum present in many pre-service teacher programs at universities.

\footnotetext{
${ }^{6}$ According to Amnesty International, Blacks represent $77 \%$ of the young people killed in Brazil (See also https:/ / anistia.org.br/noticias/anistia-internacional-lanca-campanha-sobreo-alto-indice-de-homicidios-de-jovens/), and, according to the National Forum of Public Security, Black people (youth and adults) who were murdered at gunpoint represented $71 \%$ of all deaths from 2005 to 2015 (See also https://g1.globo.com/sp/sao-paulo/noticia/ negros-representam-71-das-vitimas-de-homicidios-no-pais-diz-levantamento.ghtml).

7 According to the Brazilian Institute of Geography and Statistics database of 2015 Black students proportion rose to $34 \%$ in the last decade. In postgraduate programs this number covers a proportion of no more than $16 \%$ according to the data I published in a paper in 2018, making a point of underrepresentation of Blacks in Brazilian Science (NASCIMENTO, 2018).
} 
In this study, I seek to examine the aspects negatively or positively involving the identity performance of Black English language teachers, triggering them to be resistant identities in language or resistant identities to language. My primary hypothesis, when I first raised the underlying reasons for this research, was to believe that Black teachers, as resistant identities in/through language, taking for granted that, even with their wariness about facing difficulties in a field mostly occupied by Whites, these Black people would resist and would not give up their own trajectories. Examples of the opposite behavior, which run against the one I expected to encounter in my research, is the discourse of Black teachers who, since they are being discredited, plan to pursue another job/career. This can be understood as a form of the negative performance of those teachers' identities, especially as regards the way they can drag language into their own behavior as something not meant for them and English teaching as a thing he/she is not competent enough to work with. The hypothesis I address here has to do with my background as a researcher in South Bahia (in a nation and state that is a product of a horrific history of colonization, enslavement, and decimation, which continues to exist based on the initial claims of this article) and from data collected for a wider research project in Applied Linguistics, seeking to investigate whether race is a variable negatively or positively performed in the career pursued by Black English language teachers.

This article will analyze autobiographical narratives I collected as partial fulfillment of the requirements for my Ph.D. research. I collected these autobiographical narratives from two in-service Black English language teachers working for public schools in both South Bahia and the Jiquiriça Valley, regions of the state of Bahia, Brazil. This article aims to identify which identities in language they constructed as a process of their own existence amidst our leading assumptions about the low proportion of Black people in English language teaching.

In the early backgrounds of this article, I will draw on Frantz Fanon's (2008) standpoint regarding language and racism. He has long been committed as an activist and anticolonial theorist seeking to analyzing the multifaceted sides of racism, including those existing in language. Thus, he believed racist structures were given to maintain a zone of non-being through colonial fashions, to generate subjugation of Black people in that zone, generating what he defines as "White masks" (FANON, 2008, p. 9). In a broader sense, White masks are marks of repetition Black people must 
follow to be considered humans like White people. Further, Fanon (2008) shapes language as a White mask. To elaborate on that, he provides an example of the case of Black people who attempt to speak a "White French language" (FANON, 2008, p. 33) so that they can appear to be superior among other Black people.

For this purpose, I will take into consideration his remarks on race and language (FANON, 2008) by following up the narratives of Blacks from the Antilles (now Martinique) and their social representation in French language (the way either they thought of language to escape the zone of non-being or the way they saw language as their way to appear superior among the others) in contrast to their own native languages. I refer to the zone of being, defined previously by Fanon (2008), as a zone below humanization (being), where Black people live. That zone was created because of European colonization, enslavement of Africans, and the decimation of indigenous communities. According to Fanon (2008), Whiteness, Europeanness, and modernity created Black as a non-human sign, as an animal. The Black scholar, Souza (1990), supports my arguments on racism and coloniality, as well as the repetition of whitening among Black people. She stressed the ways Black people repeat White patterns in Brazil. I also build on Aimé-Cesaire's (1972 words, in his attempt to locate the models of dehumanization conducted by racism in the colonial processes of dispossession inherited by Black people, where Black people were being portrayed as animals in the Western discourse. Moreover, I will embrace the accounts Achille Mbembe (2014), who comprehends race and language not only as a sign of oppression, but also as a sign of resistance to racism and its shared ways, thus performing a double sign (GATES JR., 1988).

Seeking to examine linguistic efforts to put forward racial bias in language studies, I will use the theorizations of Philipson (1992), Souza (2011), and Pennycook (2002) to emphasize the role of colonialist and imperialist discourses in English language teaching around the world.

\section{Language in racialization and racialization in language}

The amount of literature in the social sciences has long neglected one of the most important voices in the twentieth century - Frantz Fanon. Although the literature of each country where colonization has been a major, historical process of cultural, social, and economic traditions, focusing their 
scholarship on neoliberal problems, coloniality in Latin America received little or no attention by scholars (WINDLE, 2018). Souza (2011) points out local identities to resituate global identities towards analyzing global citizenship critically. Nevertheless, since local identities are still unrecognized globally, Black scholars have remained neglected, and the scholars from White elitist castes from ex-colonized countries remained the few intellectuals who have been cited in works related to race and racism.

In this sense, Frantz Fanon's early works spoke greatly of coloniality, race, whiteness, and ways to perform decolonization that have only recently become the bibliography of social studies in the Western world.

His first concerns in that book are about the relation between blackness and language. In The Negro and Language, Fanon (2008) analyzes the uses of the language spoken by Blacks in the Antilles that were drawn as a means for Whites to acknowledge the Blacks. ${ }^{8}$ He primarily began his concerns by criticizing colonization through language, advocating that "to speak is to exist absolutely for the other" (p. 8), and, compared to speaking dimensions and racial behavior, Black men have two dimensions:

One with his fellows, the other with the white man. A Negro behaves differently with a white man and with another Negro. That this selfdivision is a direct result of colonialist subjugation is beyond question. No one would dream of doubting that its major artery is fed from the heart of those various theories that have tried to prove that the Negro is a stage in the slow evolution of monkey into man. Here is objective evidence that expresses reality (FANON, 2008, p. 8).

As noted by Fanon (2008), White masks are a sign that has been signified by colonialism through the imitation of White patterns for the Whiteness to accept Black people. ${ }^{9}$ In Brazil, Neusa Santos Souza (1990)

\footnotetext{
${ }^{8}$ In this article I am using Blacks and Black people to refer to the same racial population. Moreover, I will be using Blacks, Black people and African descendants to refer to the same population. Although these uses do not fit into English grammar, they became a usage that is recurrent among Black people in the Anglophonic African Diaspora.

${ }^{9}$ In this article, in a close proximity to Alcoff (2015), I understand whiteness as an institution on the move over the centuries, performing a total world of colonization of almost all countries around the world and also in an attempt to disavow its own responsibility for coloniality and racism.
} 
analyzed the imitation of White patterns by Blacks in her collection of several samples that evidenced a Whitening process system in Brazil:

And, as in that society, the citizen was White, the respectful services were "services of Whites", to be respectfully treated was to be treated like a White person. It was with these initial conditions to be a person who the Blacks got themselves ready for social mobility, which means: it was with the great determination to be like Whites - even though it means not be Black - that Blacks pursued to be a person (SOUZA, 1990, p. 21, emphasis in the original text).

In a sense, following the accounts of Fanon (2008) and Souza (1990), being a person/human was/is to be White or trying to assimilate to whiteness by imitation. I shall conclude, as Souza says:

The history of social mobility of Brazilian Blacks is, in this sense, the history of their assimilation to the white patterns of social relations. It is the history of the ideological submission of a racial group in the presence of another one that makes themselves hegemonic. It is the history of a negated identity, adapting to the circumstances that shape the price of recognition to the Black based on the intensity of his negation (SOUZA, 1990, p. 23).

On the one hand, as pointed out by Fanon (2008) and Souza (1990), the assimilation to White people's patterns cannot be perceived as a simple trace of colonialism, as if Black people were simple and illiterate people repeating characteristics of coloniality with no strategy to survive it, ignoring Black people's strategies to survive, but rather those who constructed their own strategies to survive in an attempt to reach better spaces in the colonial society. I assume these facts as both a complex phenomenon and a double sign of including mastery and resistance.

However, I cannot ignore the fault of colonialism that exists under logics of exploitation, not only through material oppressions, but also within a significant process of linguistic, symbolic, and discursive meanings, requiring strategies from Black people to survive. As Aimé-Cesaire (1972) claims:

[...]They prove that colonization, I repeat, dehumanizes even the most civilized man; that colonial activity, colonial enterprise, colonial conquest, which is based on contempt for the native and justified by that contempt, inevitably tends to change he who undertakes it; that the colonizer, who 
in order to ease his conscience gets into the habit of seeing the other man as an animal, accustoms himself to treating him like an animal, and tends objectively to transform himself into an animal (CESAIRE, 1972, p. 5).

Consequently, these colonial oppressions related to the portrayal of Black men as animals are also implied in language when a Black man behaves submissively in language among White people, while among his fellows he feels superior, trying to possess language in order to possess the world, as assumes Fanon (2008):

The Negro of the Antilles will be proportionately whiter-that is, he will come closer to being a real human being - in direct ratio to his mastery of the French language. I am not unaware that this is one of man's attitudes face to face with Being. A man who has a language consequently possesses the world expressed and implied by that language (FANON, 2008, p.9).

In addition, in my comprehension, speaking a language is to be closer and not to exactly be a total White man of the Eurocentric world, as Neusa Santos Souza (1990) and Fanon (2008) confirm in their later thoughts.

To illustrate this, if I look at either the variations of Portuguese language spoken in Brazil or the multilingual situation of indigenous communities, I also wonder why Portuguese is the only official language in a country with over 180 Indigenous languages. As Souza (2004) points out, it is still a means that can help sustain colonial power through the support of official language policies:

Previous constitutions had denied full citizenship to the indigenous populations, attributing to them the status of wards of the State. Schooling had existed in indigenous areas, but with no specific legislation, it followed the norms of non-indigenous rural schools and was generally run by local authorities or by missionaries. Far from being "bilingual and intercultural," these older schools implemented policies of varying degrees of outright cultural and linguistic assimilation (SOUZA, 2004, p. 5, emphasis in the original text).

Although Indigenous people were simple wards of the State, Brazil still recognizes the Indigenous people as a problem to be solved. Souza (2004) criticizes Brazilian official linguistic education that privileges nonindigenous traditions, with non-Indigenous teachers, as he continues: 
The recent bilingual and intercultural indigenous education policies in Brazil and the establishment of indigenous schools tend to occur under the tutelage of monolingual, non-indigenous specialists, generally linguists or anthropologists, well-meaningly conscious of the objectives of the new policy to preserve and protect indigenous languages and cultures. With this in mind, these specialists are keen to see as much of indigenous knowledge and language written down for posterity and to be disseminated in the indigenous schools (SOUZA, 2004, p. 7).

In this context, language tends to be a vein of colonization, the enslavement of Blacks, the decimation of Indigenous people, and the mainstream to help pave the way for colonial masks.

Veronelli (2016) covers the possibility of a dialogical lens among peoples oppressed by coloniality. She fleshes out the colonial differences not as a way to divide, but as responsible for encouraging a dialogic dialogue among all the oppressed peoples. This also encompasses the possibilities of both rebellion and future resistance.

In short, this is also to say that language must be seen as bound to social injustices, as injustices can often be performed in and through language, with the use of beliefs, myths, and repertoire toward colonial mastery. As mentioned above, the postcolonial theorist Frantz Fanon (2008) chose language as his first concern:

To speak means to be in a position to use a certain syntax, to grasp the morphology of this or that language, but it means above all to assume a culture, to support the weight of a civilization. Since the situation is not one-way only, the statement of it should reflect the fact. Here the reader is asked to concede certain points that, however unacceptable they may seem in the beginning, will find the measure of their validity in the facts (FANON, 2008, p. 8).

More broadly, Black people seem, as analyzed by Fanon (2008), to perform their own identities in language by repeating patterns of language to abandon their own original identities (and local realities) to survive coloniality. Language is not performed out of power, but as its own boundary as such:

The progression of one type of imperialist control to another parallels the way power can be exerted by means of sticks (impositional force), carrots (bargaining), and ideas (persuasion). Language is the primary 
means for communicating ideas. Therefore, an increased linguistic penetration of the Periphery is essential for completing the move away from crude means, the sticks of colonial times, and even the core discreet means of the neo-colonialist phase of asymmetrical bargaining, to neoneo-colonialist control by means of ideas (PHILIPSON, 1992, p. 53).

In this matter, English Language Teaching (ELT) is bound to policies of coloniality and imperialism that have been used to maintain control over ex-colonies. It is by no mere chance I am writing this text in English alongside a criticism in which I also engage about linguistic imperialism within this same article. It should not be read as hypocrisy, but when we researchers who write and publish in our languages write in English as well, we also have the chance to speak for our people and for those who do not know our history, taking the chance to report language as power and as an opportunity, not neglecting our critiques to English as a colonial and racist weapon. It means strategy and not alienation from me. In this same vein:

It seems to me, having been involved for many years with teaching English as a so-called second or foreign language, that there are deep and indissoluble links between the practices, theories and contexts of ELT and the history of colonialism. Such connections, I want to suggest, run far deeper than drawing parallels between the current global expansion of English and the colonial expansion that preceded it. Rather, I want to argue that ELT theories and practices that emanate from the former colonial powers still carry the traces of those colonial histories both because of the long history of direct connections between ELT and colonialism and because such theories and practices derive from broader European cultures and ideologies that themselves are products of colonialism. In a sense, then, ELT is a product of colonialism not just because it is colonialism that produced the initial conditions for the global spread of English but because it was colonialism that produced many of the ways of thinking and behaving that are still part of Western cultures. European/Western culture not only produced colonialism, but was also produced by it; ELT not only rode on the back of colonialism to the distant corners of the Empire, but was also in turn produced by that voyage (PENNYCOOK, 2002, p.19).

In this respect, race and language interplay while they are shaped in their relation to colonial power. Even in theory, whereas it is considered sometimes confusing for many scholars (in their effort to disavow their responsibility for racism or whenever they consider Black people to be 
engaged only as participants of research and not as researchers who can leave their scholarly impressions about their own reality), it is the moment the epistemic racism that is set, as analyzed by Mignolo (2011). Examples of this are the amount of discussions over educational systems and a total absence of references to local Black scholars talking about the coloniality and racist bias the neoliberal agenda takes to developing countries. On the other hand, in many works developed by White scholars about coloniality, global and local changes are often overestimated.

Yet it merits much discussion because race and language work, not only as a weapon used to promote epistemicide through abyssal thinking ${ }^{10}$ (SOUSA SANTOS, 1997), but also as a sign of resistance. As it is resistance, it consists of strategies to survive whenever racialization creates the Black person.

But what should we understand by Blacks? It is commonly accepted that, of Iberian origin, this term will only appear in a text written in French in the early sixteenth century. It will therefore be only in the eighteenth century, that is, at the peak of the slave trade, which it becomes usable, definitively (MBEMBE, 2014, p. 76, emphasis in the original text).

Black is a concept given to me and not a sign designed by myself. Therefore, we must describe race as a sign designed for oppression, but also signified in terms of resistance. I call race a double sign, informed by Gates Jr. (1988), who analyzes the signifying monkey. Once Esù Elegbara, a Black deity from Africa, disappeared from the African-American diaspora, different from its representation in the Brazilian black-based religion, Candomblé, a story of a signifying monkey came to be continuously present in Black literature in the US. For Gates Jr. (1988), the signification provided by that metaphor demonstrates Black people edited the sign of enslavement they received and signified it as resistance towards freedom. Rather than a simple metaphor, Gates Jr.'s (1988) signifying monkey instantiates that Black people used language not as a chain, but as a means of resisting against colonial chains. It further elaborates on what Frantz Fanon (2008) perceived as White masks, producing the point of resistance of Black people in the so-called zone of non-being.

${ }^{10}$ Namely, the death of the knowledge of others headed by coloniality, according to Sousa Santos (1997). 
It was what Moura (2014) discovered as a result of his research on the history of slaves, quilombo-communities, ${ }^{11}$ and Black guerrillas in Brazil. Black people from the quilombo-communities used to perceive, in the perverse concept of race given to them, a means through which to reunite African descents (i.e. Nagô-Yorubas, Gege, Ashanti folks etc.) in Brazil. On the rise of these findings, taking Mbembe's accounts of race as a sign of oppression, but also as a sign of resistance, I understand race and language implied mutually as means of resistance. That means Black people used the sign Black not only to view it only as a sign of oppression, but also as a redesign towards resistance.

\section{Tagging the fashions of racism in language: a short review}

Racism is a system that entails inequalities, including those inequalities that are produced in the arena of knowledge (CARNEIRO, 2011). The way racism and language are mutually implied has been described by Fanon (2008), and in current research in Applied Linguistics.

Thus far, Kubota (2004, 2014), Zacharias (2010), López-Gopar and Sughrua (2014), Souza (2004, 2011), Ferreira and Camargo (2013), Ferreira (2012, 2014, 2015), Mastrella-de-Andrade and Rodrigues (2014), LópezGopar and Sughrua (2014), and Rosa and Flores (2017) are some of the voices who are concerned about the inequalities that exist in Language teaching and who are questioning the role of Applied Linguistics in this context.

A critical point concerning liberal multiculturalism and its trends in the educational system in the United States is made by Kubota (2004, 2016). In her research, she has been arguing that neoliberalism and liberal multiculturalism are provoking exclusionary changes in second language education:

One of the most problematic conceptions that second language educators need to debunk is cultural and ethnic essentialism and identity construction. As discussed earlier, it is important to understand that images of the Other and Self are neither natural nor neutral but are

\footnotetext{
${ }^{11}$ According to Moura (2014), a quilombo-community is known in Brazil for having been a territory where slaves went when fleeing from captivity, but mainly the territory where ex-slaves resisted slavery and enslavement.
} 
discursively constructed and are influenced by, and reinforce binary thinking within, unequal relations of power (KUBOTA, 2004, p.44).

That is to say that racialization means a process embedded in the way languages are taught. Predominantly, if we put forward the case of foreign language or second language education, essentializing non-white identities is referred to as a weapon used on the neoliberal and multicultural agenda to empower Whiteness.

She also questioned the increasing use of terms such as "multi/ plural", as it is given in the use of multilingualism and multiliteracies (with funding provided by neoliberal programs), which seems to value diversity and at the same time neglects diverse people who want to speak, as she argues:

In critically examining the multi/plural turn, my focus is not specific arguments made in applied linguistics literature, but rather a macro discourse on plurality and hybridity that has attracted so much attention. Neither is it my intention to deny the significance and utility of the multi/ plural turn in understanding linguistic forms and practices. In fact, these conceptualizations are valuable as they challenge a broader political and educational discourse that privileges a dominant language and culture. My aim is instead to encourage us to critically reflect on ideological complicities that undermine the philosophical impetus of the multi/ plural turn (KUBOTA, 2016, p.3).

In other words, we should analyze critically the educational system policies, primarily those used to encourage social and racial inequalities and by which the system seems to be discrete and silent. The mastery of English, for example, has been used to prove a cognitive competence that differs languageless people from those who can speak English:

Indeed, while our discipline engages with multi/plural frameworks, we continue to see not only the dominance of English and standard language ideology but also ethnic conflicts, civil wars, racism, xenophobia, and growing economic gaps both nationally and internationally. While applied linguistics alone will not cure these social evils, some are within the purview of our discipline, and the gap between our celebrated 'multi/plural' perspectives and real lives of many people concerns me (KUBOTA, 2014, p.2). 
Shaping a similar discussion, Zacharias (2010) developed her research questioning the dichotomy of native speakers versus non-native speakers in pre-service teachers' discourses, which is mostly reinforced by speakers born in the USA, which in my opinion serves to ensure a dominance of an alleged competence of native speakers in comparison to non-native speakers.

As matter as fact, as also claimed by Norton (1997) and Kubota (2009), this dichotomy has helped pave an increasing myth in the second language education in such a way that it reinforces negatively teachers who are not born in the Anglophone countries.

I claim here, under what Byram (1997) claims, that a supposed superiority of the native speaker in terms of competence in contrast to nonnative speakers could not be proved so far, although it engendered a myth that is accepted in the most varied educational contexts as a truth:

There is a prevailing myth in the EFL pedagogy that to succeed academically, English as a Foreign Language (EFL) students need to minimize, if not get rid of, their ethnic (L1) identities and adapt to native speaker norms and standards (ZACHARIAS, 2010, p. 26).

To back the idea that ethnic identities are inseparable from individuals, Souza $(2004,2011)$ investigates the significance of visual literacy in Indigenous writing, confronting the official policies of Indigenous education in Brazil, which hires non-indigenous teachers who accustom themselves to ignore the multiple multimodal ways of writing beyond the alphabetic ones. Therefore:

In general, like the courses, these materials tend to be produced under the tutelage of Brazilian non-indigenous, monolingual specialists, for the most part, linguists and anthropologists. Besides being in Portuguese, a large proportion of these written materials is multimodal in nature; that is, in nature; that is, they contain a high degree of visual texts (mainly colored drawings) which accompany the written alphabetic texts, though the relationship between the alphabetic and the written may not always be clear (SOUZA, 2004, p.6.).

Also gathering the questions of racial inequalities in language teaching, the studies developed by Ferreira (2012, 2014, 2015) set the concerns surrounding the design of racial identities in English language course books and teacher training: 
Course materials are an example of ethnic divide and racism in the schools, as many books reproduce sexist, classist, and racist discrimination, especially the English language course books, which are tagged by a whitening ideology, positing whites in a position of superiority in relation to blacks, as demonstrated in recent research in the realm of Applied Linguistics (FERREIRA AND CAMARGO, 2013, p. 180). ${ }^{12}$

In short, I am presenting here a short review of much of what was developed in the field of Applied Linguistics regarding the ways racism can affect linguistic relations and linguistic relations can imply racism. In their arguments, in a recent study, Rosa and Flores (2017) termed racionlinguistics ${ }^{13}$ to locate a close relation between language and racism in educational contexts. Much of what they are concerned with emerged as a central remark of what I comprehend as putting forward the inequalities existing in Language teaching, which are not commonly named as racism.

\section{Materials and methods}

For this study, I collected autobiographical narratives from Black English language teachers from South Bahia to analyze whether their racial identities have been set up negatively or positively in relation to language, thus aiming to analyze the paths that led them to be English teachers.

The data collected in Brazil for this article are samples of field notes and an interview with two in-service Black teachers in ELT from different cities in South Bahia. The Black teachers were chosen because they make up a low proportion of Black English language teachers in Bahia, the blackest state in Brazil.

Based on Chizzotti (2006), I first collected autobiographical narratives of these teachers to be analyzed. I privileged autobiographical narratives to shed light on the theories cited in this article. The first results show that no difference greater than misrepresentation was observed in these teachers'

\footnotetext{
${ }^{12}$ My translation into English of the excerpt: "Os materiais didáticos são um exemplo da divisão étnica e do racismo velado na escola, muitos livros têm uma postura preconceituosa, machista, classista - em especial os materiais de Inglês, esses são marcados pela ideologia do branqueamento, a qual sobrepõe os brancos em relação aos negros e são pesquisas recentes dentro do escopo da Linguística Aplicada conforme demonstram pesquisas recentes."

${ }^{13}$ This term was first used by Samy Alim.
} 
narratives, which clarifies the many obstacles they suffer to enter university and obtain a degree in English. They also appeared to be significantly influenced by racism regarding the distrust of the community about their work as Black teachers or their loneliness to be the only Black teachers in their cities.

I analyzed the amount of data at the core of the search for the means of resistance they embraced in their biographies. For this purpose, the data analysis is inspired by the literature on racialization and language provided in this article. As discussed earlier, black is a sign of horror that was also signified by black people in Brazil. Since it was once signified and as Black people signify it again, I embrace the remarks Gates Jr. (1988) advocates to further elaborate on this topic by calling Black a double sign. In fact, rather than a double sign, race is, for Black people, a double signified. Since Black people do not recognize race as theirs, ${ }^{14}$ their resistance takes to another sign involving the initial sign, leading to a double sign as I address here. Gates Jr. (1988) calls this second sign a rhetorical figure (related to signified) and signified to call on the strategies these people used to signify the original sign. Second, Frantz Fanon (2008) sheds light on the analysis while privileging language as the first tool European colonialism used so that it could colonize the entire soul of the Black people. To discuss such narratives, I will return to Fanon's concerns about language and colonial mastery in the final part of this article. Next, I will present the autobiographical narratives used in this research.

\section{Autobiographical narratives}

Our participants in this research are Black English teachers in South Bahia. The first is Rosana. ${ }^{15}$ More than 30 years old, she lives in a small town of approximately 20,000 inhabitants. She is the only teacher who is black in ELT in her town and works for private and public schools. Furthermore, she lives in a lower middle class house and told me she could only study English in a private center with a majority of White people. This happened because

\footnotetext{
${ }^{14}$ Even being a Black person, I chose to not use personal subjects. This is to say, I also occupy a double and hard role in this article as a researcher and a participant, as a Black man, and analyzing their narratives that, to some extent, are also mine.

${ }^{15}$ Fictional names were used to protect their privacy.
} 
her father, also Black, was a civil servant of the Brazilian government's Commission for Agriculture and could afford to support her.

Our second participant is an English teacher from another small town, Ana, who is one of the few Black English teachers working for public schools there. She is also more than 30 years old, and she reports her hard experiences as a consequence of her social class, which differs her situation from Rosana's story.

\section{Rosana}

Rosana is not from a rich family, but her father was a civil servant of the Brazilian government's Commission for Agriculture during her childhood. However, she was still not free of being the only Black English student at a private foreign language center, even in Bahia, a state with a population of more than $70 \%$ Blacks: ${ }^{16}$

I was trying to attend a course at the UEC English course center, which was located in Itabuna, but then it shocked me: I was the only Black over there, sure? So I've been getting so... sad, right? Black and older than them, most of the students were younger than me. Because of that, I gave up that course. [sic]

As mentioned in her narrative, she was the only Black student in her first English course in Bahia. Bahia, as mentioned above, is a state with the largest Black population in Brazil, according to the last national censuses. She also began to study English when she became an adult, in contrast to her classmates who were younger at that time. In fact, as I shall observe here, this preliminary misrepresentation or absence of Blacks in English courses can first be seen in English language courses for children and represents a preliminary attitude of the racist economic mainstream of marginalization of Black students insofar as they inherit a sense of loneliness by being the few Black students in English language courses at large. Madsen and Mabokela (2000) dwelled on this topic in a study with African American minoritized teachers of schools from the US and argued that their White colleagues practiced racism against them through attitudes of disrespect.

\footnotetext{
${ }^{16}$ These numbers are from the 2010 Census, taken by the Brazilian Institute of Geography and Statistics (IBGE).
} 
For teachers of color, part of their acculturation into a European American school requires that they acquire the necessary socialization patterns to understand their European American colleagues' codes of power. Teachers of color often are excluded and scrutinized by European and American teachers who have minimal exposure to non-Anglo norms and values. (MADSEN; MABOKELA, 2000, p. 850).

In turn, Rosana has been sponsored by a public school teacher program, which was her first experience to pursue a career as an English teacher.

It has been in this course called Freire Platform ${ }^{17}$, that I came to study the [English] language, right? On the one hand, as you know... It was alright, I loved all the approaches from the course. I learnt phonetics, phonology, everything involving a language, because the course was LEM- Modern Foreign Language, English, then, all involving English, even Literature that I had no much background yet, right? That is why the courses of private centers like CCAA are elementary, they do not actually teach the knowledge of the language, in a broad sense, right? The culture I could learn with the help of the Freire Platform program. [sic]

According to Rosana, she could only learn English and meet her goals in the government program she mentioned earlier (Plataforma Freire). During the time she studied in a government university in Bahia, and, as she noted in her observations, even in private English language centers, she could not learn English adequately to achieve proficiency. In my assumption, it seems that such social exclusion always turned her into an excluded identity which often resists speaking about racism in ELT and, taking my own experiences as an self-taught English student, ${ }^{18}$ racism can be engendered as a major barrier to achieving proficiency in English courses. As observes Alcoff (2006, p.195): "the historical legacy of racial identities will always carry as a central feature the history of racism, and in this way there is an association of race with racism", but may produce different meanings, not

\footnotetext{
${ }^{17}$ The Freire Platform refers to an educational program created during Lula's government to develop teacher training in order to offer a first degree do teachers of secondary and elementary schools.

${ }^{18}$ My early contact with English was during my first grades in the elementary school where English language was not provided yet. Some of the autobiographical narratives of this article are experiments of my experiences as speaker/teachers.
} 
necessarily connected hierarchically to a permanent natural link between race and racism, but also leading to resistance. In the meaning constructed in Rosana's context, she was not as poor as most of her friends, but she was the only Black student at her first English course in a private center, framing a path of exclusion envisioned by racism. Even with the minimally better conditions of social class that she experienced, this did not testify against the likelihood of her racial narratives.

I was also concerned about the knowledge she constructed during the period she was in elementary and secondary education as a student. The precariousness of education is another means of constructing invisible and silent identities which perform their narratives as resistant identities in language or resistant identities to language, or entangling both positions, like Rosana seems to be. Fighting this kind of precariousness in public school education is a means of facing colonialism. Regarding these means of facing racism, Walsh (2007) maps the steps used by the World Bank to co-opt identities in the emerging countries through a neoliberal agenda of precariousness:

By assuming interculturalism within State policy and discourse, and similarly within the discourse and policies of multilateral institutions such as the World Bank, its fundamental transformative meaning, as conceived by the indigenous movements, is weakened and co-opted (WALSH, 2007, p.55).

Hence, it is important to stress that precariousness in Brazilian education is one of the products of neoliberalism and World Bank policies, which have undermined the possibilities of economic, social and cultural access of ethnic and racialized people. As such, Rosana's discourse seems to represent a sample of this context. This precariousness is reflected in Rosana's claim that she is the only Black English teacher in her city when she has been asked about her assessment about English courses she attended in the public schools attended as a student:

No no no no [about good English teachers in her schools when she was a student]. Actually I did not learn anything at school, right? Unfortunately, most [of teachers], most, and [this situation] still happens, and in my city it is only me [as an English teacher], in a city of more than almost 30 thousand inhabitants, only one [black] English teacher. 
The fact that she is the only Black English teacher in her city unveils that racism works to set limitations and borders to racial identities which are fragmented and isolated in their positions of Blackness.

\section{Ana}

Ana never believed she could be an English teacher, as she says:

I practically fell from the sky in the English teacher training course. When I was a student I did not give much importance to it. Poor, everyone was illiterate at home. "What are you going to use English for?", they used to ask me. So I did not give enough value to English back then. When I first applied to enter the university, I took 0 in the English exam so I had to look for a private English course to improve my English to apply again. Then it was while studying Letras [Language] with English as a second language that I got satisfied.

Ana was poorer than Rosana, according to the field notes of the preliminary data from this study, but she could only enter the university after attending a private course at an English language center. This reveals the precariousness in education for English language teaching and learning when teachers are Black.

Even in the English degree, she faced a wide range of difficulties:

It was hard because some of my colleagues already had a certain proficiency in English and I was a beginner and the teachers taught as if everyone was fluent over there. This took me to a certain nuisance and sometimes I had some argument with my colleagues because they were more advanced in English and they did not want the teacher to help the ones who had more difficulties. Then I have been all the time angry and pissed off of being there ... [sic]

In this light, English degree courses also have many precarious contexts for students who did not speak English before entering university. Prior to entering university, most White students pay and attend private ELT courses. Likewise, professors at the university also disconsider those who have not learned how to speak English previously, which serves as an obstacle for those poor and Black students, leading them to think about giving up the programs. It was not Ana's case because, as she says, in her case, she resisted during her course. 
Thus, building on the White masks in Fanon (2008), I refer here to the context in Brazil and Bahia, and particularly in a state such as Bahia, with the highest Black population outside the African continent, following up the ways White masks are represented in exclusionary contexts for Black students in language education. Some other findings in this article report that, in her city, she is also one of the few Black English teachers. Despite being victim herself of the institutionalized system of White masks, she believes language is a kind of possibility for emancipation:

In fact, language is also a way of emancipation and empowerment. It's a way for us to also face racism. They always see Blacks related to history, philosophy, sociology, so many people asked me: you graduated from history, right? I've always been the opposite of that.

In short, I can say that resisting in and through language teaching has saved Ana and Rosana from low self-esteem processes, which lead Black people to loneliness and self-abandonment. As Ana herself fleshes out, she believes in the opposite of the stereotypes imposed upon Black teachers, and she uses language teaching herself as a performance to fight racism.

\section{Discussion, considerations, and future developments}

As a professor/researcher also at stake in this study, in this article I analyzed preliminary data collected for research ongoing as a Ph.D. student of a graduate program in Brazil with ongoing data collection towards an autoethnographic research.

I could also address my lens in this research because of my previous career as an English teacher in South Bahia (and now as a tenured Black professor), which led me to meet few Black colleagues or many Black colleagues with multiple difficulties during English language courses during my trajectory.

This peaked my interest in this research and I could follow many colleagues suffering from many situations often influenced by racism in their professional activities, which were similar to those situations I faced in my own professional background.

The amount of data observed in this article has bolstered some of my preliminary quests as a researcher and scholar, which previously led me to the research path in my Ph.D. Thus, whereas unhappy and hurt as 
a Black person influenced negatively by racism every single day, I could recognize in the Black teacher's narratives the way Black identities not only survive racism, but how they also create strategies to survive the permanent marks of racism. These strategies I call, considering the early backgrounds developed by Tílio (2010) in Brazil, as resistant identities in language, or, as I am using here, the double-sided sense of racism, which is also translated into forms of resistance. It entails language as a pathway to fight and resist as racial performers and as people who use all the strategies to be resistant in a place in which racial exclusion implies practices occurring from the onset, which I shall recognize as language.

Both of the interviewed teachers, Rosana and Ana, differ greatly from each other, but they are also similar, as they know their role as English teachers within their own situations. In her assumptions, Rosana poses the reasons (she is aware) concerning how racism is a factor that draws myths, such as the belief that students do not even know how to speak Portuguese correctly and, in this sense, they cannot follow English lessons because they allegedly do not master their own Portuguese language. Ana, in turn, discloses in her narrative about how she is incorrectly seen as a History, Philosophy, or Sociology teacher simply because she is Black. She seems to be aware that this is a feature brought about by racism regarding her experience.

The vein of their narratives can frame the embedded hypothesis in my research that racism is an acquainting reality in their life, which tags them to face daily subtle meanings of racism, but also provides a fashion of resistance from both participants in/through language. This has to do with the opposite racial site conveyed for them historically, which produces inequalities everywhere, even in majors of teacher training in the English language. It also unveils that, on the contrary of the plea for determinism and conservation, which reportedly lead Black identities to accommodation, if racism and coloniality is unpacked in/through language, identities may strengthen their trajectories to provide positive outcomes in the fight against racism. In terms of Fanonian thoughts, stressing his emphasis of the Black people from the Antilles who attempt to speak like the colonizers in order to appear as whiter, Ana and Rosana seem to play a different role in Language. Since they are used to resisting and aware of racism, they play a remarkable role in the sense that they recognize themselves as Black teachers who must unfold the obstacles in their stories. 
Whereas Fanonian analysis of Language claims to take Language into consideration regarding coloniality, which is reinforced in daily White masks, my research and collected data point to identities which claim themselves to also be resistant in Language (using language as a strategy to resist coloniality). Thus, language and race took on a double sense in their narratives: negatively, they were suffering; positively, they embraced resistance to shape a new significance within it. It is the assumptions that Mbembe (2014) makes to refer to the future of race as an overgeneralizing site of racialization that, as long as it is causing global effects in the current neoliberal age, it is also an up-and-coming Black person in the world who sheds lights of resistance upon the world at the same time.

Much of what I have claimed concerning race and language in this article must also take into account the possibilities of social change through the claims and strategies emerging from Black voices. This was the effort embedded in this article, though it is not enough. It can produce our multiple views that, if racism and inequalities are growing and adapting themselves rapidly to a multicultural turn, then Black people are also acting as resistant identities. Therefore, we should wonder (calling upon Applied Linguistics within this site) whether we are really focusing our efforts toward hearing from more Black voices, or whether we are merely speaking of and instead of them within racist perspectives.

\section{References}

ALCOFF, L. The Future of whiteness. Cambridge: Polity Press, 2015.

ALCOFF, L. Visible identities: race, gender, and the self. Oxford: Oxford University Press, 2006. Doi: https:// doi.org/10.1093/0195137345.001.0001

BYRAM, M. Teaching and Assessing Intercultural Communicative Competence. Clevedon: Multilingual Matters, 1997.

CARNEIRO, S. Racismo, sexismo e desigualdade no Brasil. São Paulo: Selo Negro, 2011. CESAIRE, A. Discourse on colonialism. New York: Monthly Review Press, 1972. CHIZZOTTI, A. Pesquisa qualitativa em ciências bumanas e sociais. Petrópolis: Vozes, 2006.

FANON, F. Black Skin White Masks. London: PlutoPress, 2008.

FANON, F. Toward the African Revolution. New York: Grove Press, 1964. 
FERREIRA, A. J. Autobiographical narratives of race and racism in Brazil: Critical Race Theory and language education. Revista Muitas Vozes, Ponta Grossa, v. 4, n. 1, p. 79-100, March 2015. Doi: https://doi.org/10.5212/MuitasVozes.v.4i1.0005

FERREIRA, A. J. Identidades sociais, letramento visual e letramento crítico: imagens na mídia acerca de raça/etnia. Trabalhos em Linguística Aplicada, Campinas, v. 51, n. 1, June 2012. Doi: https://doi.org/10.1590/S0103-18132012000100010 FERREIRA, A. J. Teorizando Relações Étnico-Raciais no Brasil. In: SIERRA, J. C.; SIGNORELLI, M. C. (org.). Diversidade e educação: intersecções entre corpo, gênero e sexualidade, raça e etnia. Matinhos: UFPR Litoral, 2014. v. 1, p. 83-103.

FERREIRA, A. J.; CAMARGO, M. O racismo cordial no livro didático de língua inglesa Aprovado Pelo PNLD. Revista da ABPN, Goiânia, v. 6, n. 12, p. 177-202, Nov. 2013.

KUBOTA, R. Critical Multiculturalism and Second Language Education. In: NORTON, B.; TOOHEY, K. (ed.). Critical Pedagogies and Language Learning. Cambridge: Cambridge University Press, 2004.

KUBOTA, R. Rethinking the Superiority of the Native Speaker: Toward a Relational Understanding of Power. In: NERIKO, M. D. (ed.). Native Speakers Revisited: Multilingualism, Standardization, and Diversity in Language Education. New York: Mouton de Gruyter, 2009. p. 233-247. Doi: https://doi. org/10.1515/9783110220957.233

KUBOTA, R. The Multi/Plural Turn, Postcolonial Theory, and Neoliberal Multiculturalism: Complicities and Implications for Applied Linguistics. Applied Linguistics, Oxford, v. 37, n. 4, p. 474-494, Aug. 2016. Doi: https://doi.org/10.1093/ applin/amu045

LÓPEZ-GOPAR, M. E.; SUGHRUA, W. Social Class in English Language Education in Oaxaca, Mexico. Journal of Language, Identity and Education, [S.l.], v. 13, n. 2, p. 104-110, 2014. Doi: https://doi.org/10.1080/15348458.2014.901822

MADSEN, J. A.; MABOKELA, R. O. Organizational Culture and Its Impact on African American Teachers. American Educational Research Journal, New York, v. 37, n. 4, p. 849-876, March 2000. Doi: https://doi.org/10.3102/00028312037004849 MBEMBE, A. Crítica da razão negra. Lisboa: Antígona, 2014.

MIGNOLO, W. El pensamiento decolonial: desprendimiento y apertura. Un manifiesto. In: CASTRO-GÓMEZ, S.; GROSFOGUEL, R. (ed.). El giro decolonial: reflexiones para una diversidad epistémica más allá del capitalismo global. Bogotá: Siglo del Hombre Editores, 2007. p. 25-46. 
MOITA LOPES, L. P. da. Pesquisa interpretativista em Lingüística Aplicada: a linguagem como condição e solução. D.E.L.T.A., São Paulo, v. 10, n. 2, p. 329-338, March 1994.

MOURA, C. Rebeliões da senz̧ala: Quilombos, insurreições, guerrilhas. São Paulo: Anita Garibaldi, 2014.

NASCIMENTO, G. O negro na ciência brasileira contemporânea através de duas amostras. Revista Eletrônica Espaço Acadêmico, Maringá, v. 18, n. 206, p. 110-123, July 2018. Doi: https://doi.org/10.18256/2447-3944.2018.v4i1.2339

NORTON, B. Language, Identity, and the Ownership of English. Tesol Quaterly. Alexandria, v. 31, n. 3, p. 209-429, 1997. Doi: https://doi.org/10.2307/3587831

NÓVOA, A. O espaço público da educação: imagens, narrativas e dilemas. In: . (org.). Tempos de formação. Lisboa: Fundação Calouste Gulbenkian, 2002. p. 237-263.

PENNYCOOK, A. English and the Discourses of Colonialism. London: Routledge, 2002. Doi: https://doi.org/10.4324/9780203006344

PHILIPSON, R. Linguistic Imperialism. Oxford: Oxford University Press, 1992.

ROSA, J.; FLORES, N. Unsettling Race and Language: Toward a Raciolinguistic Perspective. Language in Society, Cambridge, v. 46, n. 5, p. 621-647, Nov. 2017. Doi: https://doi.org/10.1017/S0047404517000562

SOUSA SANTOS, B. Pela mão de Alice: o social e o político na pós-modernidade. São Paulo: Cortez, 1997.

SOUZA, L. M. T. M. Engaging the global by re-situating the local: (Dis)locating the literate global subject and his view from nowhere. In: OLIVEIRA ANDREOTTI, V.; SOUZA, L. M. T. M. (org.). Postcolonial Perspectives on Global Citizenship Education. Londres: Routledge, 2011. v. 1, p. 1-246.

SOUZA, L. M. T. M. Remapping Writing: indigenous writing and cultural conflict in Brazil. English Studies in Canada, Ontario, v. 30, n.3, p. 4-16, 2004. Doi: https:// doi.org/10.1353/esc.2004.0033

SOUZA, N. S. Tornar-se negro ou As vicissitudes da identidade do negro brasileiro em ascensão social. Rio de Janeiro: Graal, 1990.

TILIO, R. C. A representação do mundo no livro didático de inglês como língua estrangeira: uma abordagem sócio-discursiva. The Especialist, São Paulo, v. 31, p. 167-192, Oct. 2010. 
VERONELLI, G. A Coalitional Approach to Theorizing Decolonial Communication. Hypatia, Washington, v. 31, n. 2, p. 304-420, 2016. Doi: https:// doi.org/10.1111/hypa.12238

WALSH, C. Interculturalidad y colonialidad del poder. Un pensamiento y posicionamiento "otro" desde la diferencia colonial. In: CASTRO-GÓMEZ, S.; GROSFOGUEL, R. (org.). El giro decolonial: reflexiones para una diversidad epistémica más allá del capitalismo global. Bogotá: Siglo del Hombre Editores, 2007. p. 47-62.

WINDLE, J. Neoliberalism, Imperialism and Conservatism: Tangled Logics of Educational Inequality in the Global South. Discourse: Studies in the Cultural Politics of Education, Melbourne, v. 40, n. 2. p. 191-202, 2018. Doi: https://doi.org/10.10 80/01596306.2019.1569878

ZACHARIAS, N. T. Acknowledging Learner Multiple Identities in the EFL Classroom.K@ata, Surabaya, v. 12, n. 1, p. 26-41, June 2010. Doi: https://doi. org/10.9744/kata.12.1.26-41

Data de submissão: 31/01/2019. Data de aprovação: 31/10/2019. 